\title{
Yield Losses of Potato Tubers due to Infestation with Gryllotalpa gryllotalpa (Gryllotalpidae: Orthoptera) and Penitodon bispinosus (Scarabaeidae: Coleopteran) Based on Insecticide Treatment at Nubaria Region, Egypt
}

\author{
Emad, M. El- Adawy1, Osman, A. Zaghloul², Ahmed, M. Kordy ${ }^{2}$, Mohamed, M.El-Shazly ${ }^{2}$ and \\ Magda,M. Khtab ${ }^{3}$
}

\begin{abstract}
The present investigation has been conducted in the two successive summer seasons of 2014 followed by the winter one of 2015, for the purpose of appraising yield losses to potato tubers caused by the two key subterranean insect pests: Gryllotalpa gryllotalpa(L), Penitodon bispinosus Kust
\end{abstract}

Potato plants were treated with two recommended doses of seven insecticidal baits at 70 and 85 days from sowing. These poisonous baits were Fipronil, Chloropyrifos methyl, Fentrothion, Dimethoate, Azadirachtin, Bacillus thuringiensis and Beauveria bassiana.

In the summer season of 2014, the obtained data revealed that loss percentages were $7.86,9.13,11.62,12.5$, 25, 25.01, 25.63 and 50 for tubers treated with Fipronil, Chloropyrifos methyl, Fentrothion, Dimethoate, Azadirachtin, B.T, B. bassiana and control, respectively.

Correspondingly 2015 as a winter season for the crop, these percentages were $3.76,6.24,12.5,12.51,25,28.12$ and $40.62 \%$ for the control successively.

It is worth mentioning, that loss percentages are considered as a prerequisite step for the determination of seven economic injury levels for each insect pest. The computed economic injury levels (EILs) values pertaining to $G$. gryllotalpa were $0.1,0.11, .011,0.31,0.10, .014,0.17$, insect/100 tubers as a result of using Fipronil, Chloropyrifos methyl, Fentrothion, Dimethoate, Azadirachtin, B.T and $P$. bispinosus, respectively. Whereas in case of the $B$. coriacea, the economic injury levels (EILs) values were $0.41,0.65,1.44,0.64,1.81,0.52$ and 1.23 insect /100 tubers were also due to the application of the same poisonous baits, respectively, for $P$. bispinosus, $G$. gryllotalpa plantation of 2014.

In the season 2015, the EILs values due to infestation by $G$. gryllotalba were $0.54,0.25,0.18,1.43,0.36,2.8$ and 0.25 insects/100 tubers for Fipronil, Chloropyrifos methyl, Fentrothion, Dimethoate, Azadirachtin, B.T and Beauveria bassiana baits, in respect. Corrispondingly, EILs the $P$. bispinosus were $0.1,0.1,0.1,3.8,0.41,0.22$ and 0.31 insect/100 potato tubers for the some applied baits, in respect.

Keywords: Potato soil insect - Insecticidal controlYield loss assessment - Economic injury levels.

\footnotetext{
${ }^{1}$ Plant Protection Institute, Agric. Res. Center, Nubaria Station,Egypt.

${ }^{2}$ Plant Protection Dept., Faculty of Agric. (Saba Basha), Alexandria Univ.

${ }^{3}$ Plant Protection Institute, Agric. Res. Center, Egypt.

Received May 24, 2017, Accepted September 20, 2017
}

\section{INTRODUCTION}

The importance of yield losses assessments caused by pest infestation on crops has been studied some reasons for making such assessments are the establishment of the economic status of specific pests (Golebiowska and Romankov, 1968); to find the infestation that justifies control (chiarappa et al, 1970) and to give a basis for directing future research and agriculture planning and forecasting (Walker, 1967 and Al-Eryan and El-Tabbakh, 2004).

Some authors have used replicated field trials to assess crop losses a result of pest infestation, using randomized blocks or on randomly selected plots in fields. In their experiments, they have kept some plots free from pests by blanket insecticide treatments or other control measures whereas the plants of the other plots are allowed to be damaged by naturally occurring populations of the same pests.

Other authors have assessed yield losses under natural field conditions either by regression analysis (Gage and Mukerji, 1978) by the analytical method (Judinko, (1973) and Al-Eryan, 2004). The analytical method is based on the comparison of yields of infested and un infested plants with specific pest which are growing under identical conditions.

From the point of view, it could be concluded that as early as in (Weiss and Dickerson 1918) mentioned that the European mole cricket Gryllotalpa gryllotalpa (or: Orthoptera, Fam: Gryllotalpidae) (L.1958) is an important insect pest in field crops in Iran. Rolston and Barlow (1980) recorded the larvae of the white grub, phyllophaga ephilida (Say) on sweet potato. Several investigators referred to Gryllotalpa gryllotalpa and P. bispinosus.(Hope) (Or: Coleoptera as serious insect pests on potato tubers in Iran ,India and Egypt. Several investigators refered to G. gryllotalpa and P. bispinosus as serious insect pests on potato tubers in Iran, India and Egypt [ Veenakumari and Veeresh (1982), Singh (1989) ,Kakate et al (1991), Bahgat (2001); (2003), Chandel et al. (2005), Chandla and Chandel (2007); Zaki (2007); Puja Rani et al (2009), Anupam Sharma et al (2012), 
Walker (1937), Sanaa, Abdel Kader (2000) and Mohammad Munib et al. (2016)].

As a matter of fact, information on $P$. bispinosus seems to be very scarce. Howevers Misra and Sharma (1987); Chandel (1992) and Mehta et al (2010), mentioned that certain insect pests may causes yield losses ranging 41.2 to 98.3 quintals/ha due to infestation with several species of white grabs. This investigation aims at adding some knowledge on the Economic injury levels (EILs) of two key subterranean insect pests on the assessment of potato tuber loss at EL-Noubaria region, Beheira Governorate Egypt.

Stern et al., (1959) defined EIL as: "the lowest population density of a pest that will cause economic damage; or the amount of pest injury, which will justify the cost of control." The present study aimed at the following two objectives: a- to assess potato tuber loses due to the combined infestation with Gryllotalpa gryllotalpa (L) and P. bispinosus. (Hope). And bapproximate (EILs) for both considered potato insect pests using different insecticide baits.

\section{MATERIALS AND METHODS}

\section{1- Experimental site and design:}

The present field investigations aimed at determining the efficacy of seven insecticide baits on the moving stages of both $\boldsymbol{G}$. gryllotalba (nymph \& adults) and $\boldsymbol{P}$. bispinosus (larvae and adult). As both pests were as major importance in potato fields in the experimental site the two potato growing seasons in summer 2014 and winter 2015 at the Research Farm of Agrofood Company, $60 \mathrm{~km}$, southwest Alexandria city, ElNoubaria, district, El-Behiera Governorate of Egypt. Arandomized completed block desingn replicated three times was used block.

In both seasons an area of $620 \mathrm{~m}$ was divided into three longitudinal blocks(replicates). Each block was then sub divided into eight (8) plots. The area of each plot measured $25 \mathrm{~m}^{2}$ and contained (6) rows of $5 \mathrm{~m}$ long $\times 0.90 \mathrm{~cm}$ wide $\times 30 \mathrm{~cm}$. height followed to there now measurement were intiont conally prevent, as much as possible the damage caused be the potato tubers moth Phthorimaea Operculella(Zeller), that infests usually plant canopy (Ministry of Agriculture)

The experimental area was cultivated with the potato cv. "Vallor"., Solanum tuberosum L. (Solanaceae) on the $15^{\text {th }}$ of December,2014 as a summer plantation potatoes were sown on $25^{\text {th }}$ of September, as a winter plantation. Potato tubers "grade A" were imported from Scotland. They were sown in each plot at a distance of $20 \mathrm{~cm}$, I e. each plot included 126 hills. Buffer area of $1 \mathrm{~m}$ wide was left between blocks. Every two adjacent plots to avoid any interference or contamination of the insecticidal treatments.

All agriculture practices were adopted according to the recommendations of the Egyptian Ministry of Agriculture. Furthermore, $\mathrm{N}$ and $\mathrm{K}$ fertilization of the experiments all area were standardized to suit the sandy soil.

\section{2- Insecticidal treatments.}

Seven insecticides were used to induce different levels of infestation with the two considered insect pests treatment was left untreated to serve as control. Insecticidal treatments were applied as baits. Insecticidal treatments were randomly distributed in the experimental area in a RCBD. To prepare required baits, the amount each of the 7-insecticide used were thoroughly mixed with $1 \mathrm{~kg}$ Allum (potassium sulphate) $+15 \mathrm{~kg}$. ground corn kernels $+1 \mathrm{~kg}$ molas $+20 \mathrm{~L}$. of water. Before insecticidal treatment, plots were first irrigated in the morning, and the baits were evenly spread in the evening between the 2 rows 8 plants / plot. Baits were applied twice once when the plants aged 75 days and again when their age reached 85 days.

\section{3- Insecticides:}

The trade and common names of the 7 tested insecticides used in field experiments together with their formulation and application rates are shown in Table (1).

\section{4- Yield loss assessment}

All recommened agriculture practices were strictly applied to minimize as much as possible the expected damage coused by ph opercullella. G. gryllotalba and $\boldsymbol{P}$. bispinosus and the percentage of yield losses. At harvest, the tuber weight per plot were recorded as evidence of yield components. Appraisal of potato tubers loss percentages due to infestation with both was calculated according to the following that modified from the formula described by Zahid et al., (2008):

$\%$ loss percent $=[(Y o p-\mathrm{Y} t 2 \ldots 5 / \mathrm{Yop}) \times 100]$, Where: -

Yop $=$ optimal yield. Yt $2 \ldots 5=$ yield for each insecticidal treatment.

\section{5- Determination of economic injury levels (EIL).}

The equation used for the determination of insecticidal treatments on potato tuber yield were based on the study of

Following steps in order:

1- Recording yield loss due to potato tuber injury then working out the better- fit equation to find out a regression coefficient. 
Table 1. Trade names, commen names, formulation and dose of tested insecticides

\begin{tabular}{|c|c|c|c|c|}
\hline Group & Trade name & Common name & Formulation & Application rate \\
\hline Phenylpyrazoles (Fiproles) & $\operatorname{Coach}^{\circledR}$ & Fipronil & $\mathrm{SC}$ & 1 litre /fed. \\
\hline \multirow{3}{*}{ Organophosphates } & Houky ${ }^{\circledR}$ & Chloropyrifos methyl & $\mathrm{EC}$ & $250 \mathrm{~cm} / \mathrm{fed}$ \\
\hline & $\begin{array}{l}\text { Sumithion } \mathrm{K}^{\circledR} \\
\mathrm{Z}^{\mathbb{B}} \text { EEEEEEEEC }\end{array}$ & Fenitrothion & $\mathrm{EC}$ & 1 litre / fed. \\
\hline & Perfecthion $40 \%{ }^{\circledR}$ & Dimethoate thuringiensis & EC & $500 \mathrm{gm} / \mathrm{fed}$. \\
\hline \multirow[t]{3}{*}{ Bio- insecticide } & Nimbecidine $^{\circledR}$ & Azadirachtin & $\mathrm{EC}$ & 1 litre / fed. \\
\hline & Protecto $^{\circledR}$ & Bacillus thuringiensis & WP & 1 litre / fed. \\
\hline & Careprotector $^{\circledR}$ & Beauveria bassiana & WP & $2 \mathrm{~kg} / \mathrm{fed}$ \\
\hline
\end{tabular}

2- Determining the economic injury level by adopting the following equations below:

\section{Control costs $(\mathrm{C} \mathrm{C})$}

a- Gain threshold (G T)

Price of one metric ton of potato

and

GT

$\mathrm{b}-\mathrm{EIL}=\frac{}{\text { Regression Coefficient }}$

Stone and Pedigo (1972). As described by in that respect, linear equations were obtained for each considered insect pest, for every tested.

\section{6- Statistical analyses:}

To compare effect of the different tested insecticidal bait treatments on EIL determination, the regression lines._Data were subjected to analysis of variance (ANOVA) using "F" test and the least significant differences (L.S.D) at $\leq 0.05$ level according to the computer program (COSTAT software,1988) and steel and Torrie (1981)

\section{RESULTS AND DISCUSSION}

\section{Yield loss assessment}

According to (khosla, 1976). it is worth mentioning that crop loss implies quantitative as well as qualiatitative reduction in yield. Earlier studies before the seventiense of century depended on the so called "guess mates" reported by many researchers and administrators in India. These guess mates were based on the following: (Pradhan,1964). Stated that 1-The absence of adequate data collected on sufficiently large scale of the key insect pest population dynamics, 2-The lack of information regarding the relationship between insect injury and its host; in the sense, paucity of knowledge about the impact of the insect pest damage on the physiological processes of the host plant and, 3The non-availability of information about the sound standardized techniques in appraising crop loss.
Therefore, crop loss estimations in the past were in it is infest stage

(Zaghloul,1982). Added that in appraising crop loss, two important points are generally considered: The first point to be taken into account in that losses caused by insect pests vary in time and space from (0- 100 depending on a large number of environmental and other biotic factors which tend to invalidate any assessment. The second point to be kept in view is the economic consideration in terms of money returns and profits to farmers, which is always variable.

\section{1- 2014 Experiment:}

A- Quantitative loss assessment in potato tubers of the season of 2014:

the effect of insecticidal treatments on the quantitative loss assessment in potato tuber in 2014 summer plantation.

In shown in Table (2), it has been noticed that the bio insecticides were less efficient than the other used chemical baits. This table refers that infested with the mean number of infested 100 potato tubers $G$. gryllotalba (adults and nymphs) were 3.33, 3.67, 3.33, 4.33. 3.67,7.67, 5.33 and 9.33 after treatment with Fipronil, Chloropyrifos methyl, Fentrothion, Dimethoate, Azadirachtin, Bacillus thuringiensis, B. bassiana and control, respectively. Correspondingly the mean number of tubers infested with by $B$. coriacea $/ 100$ tubers were $3.33,4.00,4.67,3.00,6.33,10.00$, 6.00, and 3.33 (beetles and larvae for treatments with the same abovementioned insecticide baits, respectively. Yield loss \% could be arranged descending by as follows: $50.00,25.62,25.00,13.90,12.48,9.14$ and 7.87 for control, B.bassiana, Azadirachtin and B.T, Fentrothion, Dimethoate, Chloropyrifos methyl and Fipronil.

Yields of potato tubers, represented an important factor in expressing the efficacy of the used insecticidal baits against $G$. gryllotalba and $P$. bispinosus. Comparison on basic yield /ton/fed, it indicated that 
Fipronil, was superior and yielded (19.350 ton/fed). followed by Chloropyrifos methyl (19.080 ton), Fentrothion (18.560 ton), Dimethoate (18.380 ton), both Azadirachtin, B.T and B.bassiana (15.620 ton), whereas the control yielded (10.500) ton/ fed., successively, during summer 2014 season.

Results refer that all tested chemical baits gave higher potato tuber productivity ranging from to than the bio chemicals that yielded tuber productivety of 19.350 to 15.620 ton / Fed. This means that the chemical compounds were relatively more efficient in combating the studies insect pests than that the biochemical baits.

Cumulative yield loss for G. gryllotalba and $P$. bispinosus due to both insect pests were 7.86, 9.13, $11.62,12.5,25,25.01,25.63$, and 50, successively, for the 7 tested insecticidal baits and the control.

Results referred that insecticidal treatments with Fipronil, Chloropyrifos methyl, Fentrothion, Dimethoate, Azadirachtin, B.T and B. bassiana led to subsequent low increases in the mean yield of potato, which have significant differences between them and the controls.

From the statistical point of view, it was obvious that Fipronil, Chloropyrifos methyl, Fentrothion and Dimethoate were in increasing production; with no statistical differences. among them. However poisonous baits could divided into the following three categories according to efficiency:

a- Fipronil, Chloropyrifos methyl, Fentrothion and Dimethoate, which proved to be the most efficient chemicals in killing the tow effeiciency against key pests under study.

b- Azadirachtin, B.T and B. bassiana occupied a second rank in insect potato crop yield with, no significant differences between them.

c- Control were the least treatment in producing potato tubers.

Similarly, quantitative losses in potato tubers followed the same above category.

\section{B- Quantitative loss assessment in potato tubers:}

The percentage of calculated commulative losses were $7.86,9.13,11.62,12.5,25,25.01,25.63$, and $50 \%$ for Fipronil, Chloropyrifos methyl, Fentrothion, Dimethoate, Azadirachtin, Bacillus thuringiensis and Beauveria bassian, a respectively.

\section{C- Quantitative loss assessment in potato tubers.}

The effect of insecticidal treatments on the quantitative loss assessment in potato tuber in 2015 winter plantation:
The mean number of infested potato $/ 100$ potato tubers damage by G. gryllotalba (adults and nymphs)/100 tubers were $3.00,2.33,0.67,2.00,3,7.33$, 3.33 and 7,67 after treatments with Fipronil, Chloropyrifos methyl, Fentrothion, Dimethoate, Azadirachtin, B.T, B. bassiana and control ,respectively. Corresponding the means for infestation P. bispinosus $/ 100$ tubers were $7.00,7.67,3.00,5.00,10.67,15.33$, 11.67, and 20.67(beetles and larvae), respectively (Table 3). Perecentage of yield loss percents could be arranged in a descending order as follows: $40.62,25.00$. $28.12,28.12, \quad 20.12,12.51,12.5,6.24$, and 3.76 for the control, Azadirachtin, , Beauveria bassiana, B.T, Fentrothion, Fipronil, Chloropyrifos methyl, Dimethoate. Produced yields of potato tubers could be considered an important factor in expressing the efficacy of the used insecticidal baits against $G$. gryllotalba and P. bispinosus. Comparison on baits of the means yield of potato tubers mean yield in tons / fed. Insecticide that Dimethoate, was the superior to the other tested bait treatments. With mean of 13.470 tons / fed., ton/fed. followed by Chloropyrifos methyl (13.130), both Fipronil and Fentrothion (12.250 tons / fed.), Azadirachtin (10.500 tons / fed.), both B.T, B. bassiana (10.060 tons / fed.) whereas the control yielded 8.310 ton/ fed., subsequently.

It was evident that the chemical baits resulted in higher productivity than the bio baits where Dimethoate and Chloropyrifos methyl recorded of 13.470 and 13.1312 .250 ton / Fed. respectively. This means that the chemical compounds were more successful than that of the bio baits in combating the studied insect pest.

Percentage of yield loss due to damage caused by both insect pests were 12.5, 6.24, 12.51, 3.76, 25, 28.12, 28.12 and $40.62 \%$, in respect, for the tested insecticidal baits as well as the control, due to infestation with $G$. gryllotalba and P. bispinosus (Table 3 ).

Results referred that insecticidal treatments with Fipronil, Fentrothion, Azadirachtin, B.T and B. bassiana led to less increases in the mean yield of potato with significant difference between them and the controls.

From the statistical point of view, it was obvious that Dimethoate, Chloropyrifos methyl, Fentrothion and Fipronil were in increasing production; with no statistical differences. among them. However poisonous baits could have divided into the following three categories according to efficiency:

a- Dimethoate, Chloropyrifos methyl, Fentrothion and Fipronil, which proved to be the most efficient chemicals in killing the tow efficiency against key pests under study. 
b- Azadirachtin, B.T and B. bassiana occupied a second rank in insect potato crop yield with, no significant differences between them.

c- Control were the least treatment in producing potato tubers.

As a discussion, it was evident also that both $G$. gryllotalba and $P$. bispinosus were on par in producing potato yields as well as commulative losses in potato tubers.

It was first thought that losses due to the assigned insect- pests in the summer season of 2014 would be higher than that of the winter plantation; but surprisingly the obtained results in the winter season witnessed higher losses in tubers than that of the summer one. This controversy, could be interpreted due to the long duration of both insects as well as their roaming behavior, that enable them to produce more damage to the potato crop. Additionally, the mole cricket nymphs and adults can't tolerate the relative higher temperature(Sanaa, 2002) and Munibe et al (2016), while making somewhat superficial tunnels just under the soil surface, especially in the sandy soil. This phenomenon is based on the current observations of the author.

Tables (2,3) indicated that furthermore, tested insecticidal baits insecticides acted differently between $G$. gryllotalba and, P. bispinosus. In this regard, it was clear that $G$. gryllotalba was the most susceptible to the tested insecticides rather than $P$. bispinosus. The obtained results indicated that the white grubs damaged and /or infested more potato tubers than that in case of mole cricket (Tables, 2, 3).

(Misra 1995) stated that B.coriacea was the predominant species in the north-western hills of Himachal Pradesh, India. It is damage to potato tubers ranged from 15.5 to $80.0 \%$ (based on the weight of total damaged potatoes) in prone areas.

B. Determination of multiple economic injury levels (EILs) of both $G$. gryllotalba, B. coriacea insect pests.

Table 2. Efficiency of the recommended doses of the used insecticide baits on both potato yields and cumulative loss percentages of tubers by Gryllotalba.gryllotalbaon and P. bispinosus in the summer season of 2014

\begin{tabular}{|c|c|c|c|c|}
\hline \multirow[b]{2}{*}{ Insecticidal bait } & \multicolumn{2}{|c|}{$\begin{array}{l}\text { Mean no.of infested tubers/100tubers by } \\
\text { both insect pests }\end{array}$} & \multirow[t]{2}{*}{ Yield (Ton/fed.) } & \multirow{2}{*}{$\begin{array}{l}\text { comulative } \\
\text { losses } \%\end{array}$} \\
\hline & G.gryllotalbaon & P. bispinosus & & \\
\hline Fipronil & $3.33^{\mathrm{b}}$ & $3.33^{\mathrm{d}}$ & $19.350^{\mathrm{a}}$ & 7.86 \\
\hline Chloropyrifos methyl & $3.67^{\mathrm{b}}$ & $4^{\text {cd }}$ & $19.08^{\mathrm{a}}$ & 9.13 \\
\hline Fentrothion & $3.33^{\mathrm{b}}$ & $4.67^{\mathrm{bcd}}$ & $18.56^{\mathrm{a}}$ & 11.62 \\
\hline Dimethoate & $4.33^{\mathrm{b}}$ & $3^{\mathrm{d}}$ & $18.38^{\mathrm{a}}$ & 12.5 \\
\hline Azadirachtin & $3.67^{b}$ & $6.33^{b}$ & $15.75^{\mathrm{b}}$ & 25 \\
\hline Bacillus thuringiensis & $7.67^{\mathrm{a}}$ & $10^{\mathrm{a}}$ & $15.75^{\mathrm{b}}$ & 25.01 \\
\hline Beauveria bassiana & $5.33^{\mathrm{b}}$ & $6^{\mathrm{bc}}$ & $15.62^{\mathrm{b}}$ & 25.63 \\
\hline Control & $9.33^{\mathrm{a}}$ & $3.33^{\mathrm{d}}$ & $10.50^{\mathrm{c}}$ & 50 \\
\hline L.S.D 0.05 & 1.99 & 2.15 & 1.59 & \\
\hline \multicolumn{5}{|c|}{ Means followed with the same letter (s) are not significantly different from each other at $\mathrm{P}=0.05$} \\
\hline $\begin{array}{l}\text { Table } 3 \text {. Efficiency of } t \\
\text { and } P \text {. bispinosus and } c\end{array}$ & $\begin{array}{l}\text { ted chemical -insectic } \\
\text { ive yield losses in pota }\end{array}$ & $\begin{array}{l}\text { on the rates of } \\
\text { op in the winte }\end{array}$ & $\begin{array}{l}\text { sted Potato tube } \\
\text { son of } 2015\end{array}$ & \\
\hline \multirow{3}{*}{ Insecticidal bait } & \multirow{2}{*}{\multicolumn{2}{|c|}{$\begin{array}{c}\text { Mean no. of infested tubers/100tubers } \\
\text { by both insect pests }\end{array}$}} & \multirow{3}{*}{ Yield (Ton/fed.) } & \multirow{3}{*}{$\begin{array}{l}\text { Collective } \\
\text { losses \% }\end{array}$} \\
\hline & & & & \\
\hline & G.gryllotalbaon & P. bispinosus & & \\
\hline Fipronil & $3^{\mathrm{b}}$ & $7^{\mathrm{de}}$ & $12.25^{\mathrm{b}}$ & 12.5 \\
\hline Chloropyrifos methyl & $2.33^{\mathrm{b}}$ & $7.67^{\mathrm{d}}$ & $13.13^{\mathrm{ab}}$ & 6.24 \\
\hline Fentrothion & $0.67^{\mathrm{c}}$ & $3^{\mathrm{f}}$ & $12.25^{\mathrm{b}}$ & 12.51 \\
\hline Dimethoate & $2^{\mathrm{bc}}$ & $5^{\mathrm{ef}}$ & $13.47^{\mathrm{a}}$ & 3.76 \\
\hline Azadirachtin & $3^{\mathrm{b}}$ & $10.67^{\mathrm{c}}$ & $10.5^{\mathrm{c}}$ & 25.00 \\
\hline Bacillus thuringiensis & $7.33^{\mathrm{a}}$ & $15.33^{\mathrm{b}}$ & $10.06^{\mathrm{c}}$ & 28.12 \\
\hline Beauveria bassiana & $3.33^{\mathrm{b}}$ & $11.67^{\mathrm{c}}$ & $10.06^{\mathrm{c}}$ & 28.12 \\
\hline Control & $7.67^{\mathrm{a}}$ & $20.67^{\mathrm{a}}$ & $8.31^{\mathrm{d}}$ & 40.62 \\
\hline L.S.D 0.05 & 1.55 & 2.45 & 1.05 & - \\
\hline
\end{tabular}

Means followed with the same letter (s) are not significantly different at $\mathrm{P}=0.05$. 


\section{Summer plantation of 2014}

Assessment of crop loss is a prerequisite step for the determination of the economic injury level. In this respect, the parameter of \% mean loss against the mean number of infested tubers for each insect pest was essential to get the EILs values. The total control costs including insecticides price + labour wages that differed for the different used insecticides being L.E 1710, $1500,1520,1520.1540 .1560$ and 1620 for the Fipronil, chloropyrifos methyl, fenitrothion, Dimethoate, Azadirachtin, B.T and B. bassiana, respectively (Table 4).

In regressing lines of Tables 4 losses $(\mathrm{kg})$ of potato tubers against the mean number of infested tubers by $G$. gryllotalpa:
The effect of insecticidal treatments on the quantitative loss the assessment in potato tuber in 2014 summer plantation.

Similarly, the EIL values for. the white grub, $P$. bispinosus were $0.41,0.65,1.44,0.64,1.81,0.52$ and 1.23 for Fipronil, Chloropyrifos methyl, Fentrothion, Dimethoate, Azadirachtin, B.T and B. bassiana, successively.

\section{Winter plantation of 2015}

The effect of insecticidal treatments on the quantitative loss assessment in potato tuber in 2015 Winter plantation.

Table 4. Summer of the lines regressing formula values for each considered insect pest receining different insecticidal baits for the summer plantation of 2014

\begin{tabular}{llcccc}
\hline Group & Insecticidal bait & G. gryllotalba & P. bispinosus & G. gryllotalba & P. bispinosus \\
\hline Phenylpyrazoles & Fipronil & $\mathrm{Y}=8.7012 \mathrm{X}-9.2029$ & $\mathrm{R}^{2}=0.8193$ & $\mathrm{Y}=-1.442 \mathrm{X}+10.792$ & $\mathrm{R}^{2}=0.5377$ \\
Organophosphates & Chloropyrifos methyl & $\mathrm{Y}=5.3126 \mathrm{X}-4.9207$ & $\mathrm{R}^{2}=0.6869$ & $\mathrm{Y}=1.1286 \mathrm{X}+9.8867$ & $\mathrm{R}^{2}=0.3658$ \\
Organophosphates & Fenitrothion & $\mathrm{Y}=6.5856 \mathrm{X}-7.5732$ & $\mathrm{R}^{2}=0.7656$ & $\mathrm{Y}=-0.5229 \mathrm{X}+8.94$ & $\mathrm{R}^{2}=0.1519$ \\
Organophosphates & Dimethoate & $\mathrm{Y}=2.4288 \mathrm{X}+5.8412$ & $\mathrm{R}^{2}=0.1209$ & $\mathrm{Y}=-1.178 \mathrm{X}+10.75$ & $\mathrm{R}^{2}=0.4176$ \\
Bio insecticide & Azadirachtin & $\mathrm{Y}=7.2665 \mathrm{X}+2.7927$ & $\mathrm{R}^{2}=0.6841$ & $\mathrm{Y}=0.4157 \mathrm{X}+7.9163$ & $\mathrm{R}^{2}=0.1238$ \\
Bio insecticide & Bacillus thuringiensis & $\mathrm{Y}=5.4566 \mathrm{X}+1.4622$ & $\mathrm{R}^{2}=0.7759$ & $\mathrm{Y}=1.4746 \mathrm{X}+4.7107$ & $\mathrm{R}^{2}=0.3936$ \\
Bio insecticide & Beauveria bassiana & $\mathrm{Y}=4.7696 \mathrm{X}+1.1428$ & $\mathrm{R}^{2}=0.5998$ & $\mathrm{Y}=0.6486 \mathrm{X}+7.1433$ & $\mathrm{R}^{2}=0.1614$ \\
\hline
\end{tabular}

Table 5. Winter of the lines regressing formula values for each considered insect pest receiving different insecticidal baits for the summer plantation of 2015

\begin{tabular}{lllccc}
\hline Group & Insecticideal bait & \multicolumn{2}{c}{ Y } & \multicolumn{2}{c}{$\mathbf{R}$} \\
\cline { 3 - 6 } & & G. gryllotalba & P. bispinosus & G. gryllotalba & P. bispinosus \\
\hline Phenylpyrazoles & Fipronil & $\mathrm{Y}=1.2517 \mathrm{X} 11.746$ & $\mathrm{R}^{2}=0.2998$ & $\mathrm{Y}=4.4774 \mathrm{X}+3.5207$ & $\mathrm{R}^{2}=0.5095$ \\
Organophosphates & Chloropyrifos methyl & $\mathrm{Y}=2.3317 \mathrm{X}-1.716$ & $\mathrm{R}^{2}=0.6299$ & $\mathrm{Y}=-5.6483 \mathrm{X}+36.751$ & $\mathrm{R}^{2}=0.5088$ \\
Organophosphates & Fenitrothion & $\mathrm{Y}=3.304 \mathrm{X}-2.698$ & $\mathrm{R}^{2}=0.9181$ & $\mathrm{Y}=6.443 \mathrm{X}+40.851$ & $\mathrm{R}^{2}=0.8078$ \\
Organophosphates & Dimethoate & $\mathrm{Y}=0.4203 \mathrm{X}+3.3061$ & $\mathrm{R}^{2}=0.0159$ & $\mathrm{Y}=-0.1576 \mathrm{X}+12.177$ & $\mathrm{R}^{2}=0.0003$ \\
Bio insecticide & Azadirachtin & $\mathrm{Y}=7.2665 \mathrm{X}+2.7927$ & $\mathrm{R}^{2}=0.6841$ & $\mathrm{Y}=-1.481 \mathrm{X}+29.393$ & $\mathrm{R}^{2}=0.1893$ \\
Bio insecticide & Bacillus thuringiensis & $\mathrm{Y}=-0.2177 \mathrm{X}+10.789$ & $\mathrm{R}^{2}=0.0553$ & $\mathrm{Y}=2.7843 \mathrm{X}+14.597$ & $\mathrm{R}^{2}=0.6464$ \\
Bio insecticide & Beauveria bassiana & $\mathrm{Y}=2.5825 \mathrm{X}+0.5475$ & $\mathrm{R}^{2}=0.9104$ & $\mathrm{Y}=-2.082 \mathrm{X}+33.085$ & $\mathrm{R}^{2}=0.3935$ \\
\hline
\end{tabular}

Table 6. Economic injury levels (EILs) the mole cricket,G. gryllotalba and White grubs $P$. bispinosus in 2014 winter plantation

\begin{tabular}{lcccc}
\hline Insecticidal baits & $\begin{array}{c}\text { Yield } \\
\text { (Ton/fed.) }\end{array}$ & $\begin{array}{c}\text { Total control } \\
\text { Cost in L.E. }\end{array}$ & $\begin{array}{c}\text { EILs } \\
\text { G.gryllotalba }\end{array}$ & $\begin{array}{c}\text { EILs } \\
\text { P. bispinosus }\end{array}$ \\
\hline Fipronil & $12.25^{\mathrm{b}}$ & 1710 & 0.54 & 0.1 \\
Chloropyrifos methyl & $13.13^{\mathrm{ab}}$ & 1500 & 0.25 & 0.1 \\
Fentrothion & $12.25^{\mathrm{b}}$ & 1520 & 0.18 & 0.1 \\
Dimethoate & $13.47^{\mathrm{a}}$ & 1520 & 1.43 & 3.8 \\
Azadirachtin & $10.5 \mathrm{c}$ & 1540 & 0.36 & 0.41 \\
Bacillus thuringiensis $_{\text {Beauveria bassiana }}$ & $10.06^{\mathrm{c}}$ & 1560 & 2.8 & 0.22 \\
Control & $10.06^{\mathrm{c}}$ & 1620 & 0.25 & 0.31 \\
L.S.D $_{0.05}$ & $8.31^{\mathrm{d}}$ & - & - & - \\
\hline
\end{tabular}


Table 7. Economic injury levels (EILs) the mole cricket, G. gryllotalba and White grubs $P$. bispinosus in 2014 summer plantation

\begin{tabular}{lcccc}
\hline Insecticidal baits & $\begin{array}{c}\text { Yield } \\
\text { (Tons /fed.) }\end{array}$ & $\begin{array}{c}\text { Total control } \\
\text { Cost in L.E. }\end{array}$ & $\begin{array}{c}\text { EILs } \\
\text { G.gryllotalba }\end{array}$ & $\begin{array}{c}\text { EILs } \\
\text { P. bispinosus }\end{array}$ \\
\hline Fipronil & $19.350^{\mathrm{a}}$ & 1710 & 0.1 & 0.41 \\
Chloropyrifos methyl & $19.080^{\mathrm{a}}$ & 1500 & 0.11 & 0.65 \\
Fentrothion & $18.560^{\mathrm{a}}$ & 1520 & 0.11 & 1.44 \\
Dimethoate & $18.380^{\mathrm{a}}$ & 1520 & 0.31 & 0.64 \\
Azadirachtin & $15.750^{\mathrm{b}}$ & 1540 & 0.10 & 1.81 \\
B.T & $15.750^{\mathrm{b}}$ & 1560 & 0.14 & 0.52 \\
Beauveria bassiana & $15.620^{\mathrm{b}}$ & 1620 & 0.17 & 1.23 \\
Control & $10.500^{\mathrm{c}}$ & - & - & - \\
L.S.D $_{0.05}$ & 1.05 & - & - & - \\
\hline
\end{tabular}

Regression equations for G. gryllotalpa resulted in the EILs values of $0.54,0.25,0.18,1.43,0.36,2.8$ and 0.25 (adults and nymphs) for Fipronil, Chloropyrifos methyl, Fentrothion, Dimethoate, Azadirachtin, B.T and $B$. bassiana. respectively. For the White grubs B.coriacea regression equations indicated EILs values: of $0.1,0.1,0.1,3.8,0.41,0.22$ and 0.31 for the same insecticidal baits, respectively. Similarly, regressing losses against potato tubers number of infested by $G$. gryllotalpa seven formulas were explained and obtained as follows:

It is worth mentioning, that these EILs values for the is subterranean insect pests are not permanent or constant values, but thus may differ according locality, product price, and insecticide cost. In other words, the EIL is a dynamic value.

Perusing precisely the data included in Tables (6\&7), it has been noticed that the EILs values varied among the applied insecticides. Such variations might be due to the interaction between chemicals and potato plants, which surely affect the physiological processes and pathways of plants as well as the insect pests.

The computed low EIL values in this study validated the recommended schedule of the used insecticide baits twice throughout the season as recommended by the Egyptian ministry of Agriculture management organizers.

\section{REFERENCES}

Arnold, R. W. 2008. Pedology and pedogenesis. In: Chesworth, W. (ed) Encyclopedia of Soil Science.Pp 51215.Springer, Dordrecht, Netherland.

Barshad, I. 1965. Chemistry of soil development, F.E. Bear (Ed.), Chemistry of the Soil (2nd edn.), Reinhold Publ. Co., New York (1965), pp. 1-70.

Brewer, R. 1976. Fabric and Mineral Analysis of Soils, Robert E. Krieger Publishing Co., New York.

Brewer, R. 1964. Fabric and mineral analysis of soils.John Wiley and Sons, Inc. New York, London.
Cherian, A. N. Chandrasekarand V. Rajamanickam 2004. Light minerals of beach sediments from Southern Tamilnadu, south east coast of India. Oceanologia, 46, 233-252.

Egyptian General Petroleum Corporation - Conco Coral. 1987. Geological Map of Egypt, sheet of El-Minia, Scale $1: 500000$.

EL Kady, M.M. 2008. Soils Distribution and Development of El Alamein - Wadi El Natrun Area, Egypt.M.Sc. Thesis, Fac. Agric., Al-Azhar University, Cairo.

El-Desooky, A.I. 2009.Studies on some soils in the area between SamalutsndBaharia Oasis - Egypt. Ph.D thesis, Fac. Agric., Al-Azhar University, Cairo.

FAO 2006. Guidelines for soil description, fourth edition, Food and Agriculture Organization of the United Nations, Rome.

Folk, R.L. and W.C. Ward 1957.Brazos River bar: a study in the significance of grain size parameters: Jour. Sed., Petrology, V. 27, p. $3-26$

Hammad, M.A. 1968. Genesis of the soils of the Western Mediterranean Coast of U.A.R., Ph.D. Thesis, Fac. Agric., Ain Shams Univ., U.A.R.

Hammad, M. A.; A.S.A., Abdel-Mawgoud, and A.I. ElDesooky2009. Heavy mineral analysis of some soils of an old deltaic plain in western desert of Egypt. Abstract at Mansoura Journal of Agricultural Science, Mansoura Univ., Vol. 34, No. 8, p. 9173-9183.

Haseman, J.F. and C. E. Marshall 1945. The use of heavy minerals in studies of the origin and development of soils. Missouri Agr. Exp. Sta. Res. Bull. 387.

Hubert, J.F. 1962. A Zircon-Tourmaline-Rutile Maturity Index and Independence of Composition of Heavy Mineral Assemblages with Gross Composition and Texture of Sandstone. Journal of Sedimentary Petrology, $32,440-450$.

Kasper-Zubillaga, J.J.; W.W. Dickinson; A. CarranzaEdwards, and Y. Hornelas-Orozco 2005. Petrography of quartz grains in beach and dune sands of Northland, North Island, New Zealand. New Zealand Journal of Geology and Geophysics, 48, 649-660. 
Keulen, N.; D. Frei; P. Riisager, and C. Knudsen 2012. Analysis of heavy minerals in sediments by Computer Controlled Scanning Electron Microscopy (CCSEM): Principles and Applications. In Quantitative Mineralogy and Microanalysis of Sediments and Sedimentary Rocks (Mineralogical Association of Canada Short Course Series 42), Mineralogical Association of Canada, Canada, 2012: 167184 .

Norton, L.D. and G. F. Hall 1984.Differentiation of lithologically similar soil parent materials. SSSAJ, Vol. 49 No. 2, p. 409-414.

Okhravi, R. and A. Amini2001. Characteristics and provenance of the loess deposits of the Gharatikan watershed on Northeast Iran. Global and Planetary Change, 28, 11-22.

Pye, K. and J. Mazzullo1994. Effects of tropical weathering on quartz grain shape: an example from northeastern Australia. Journal of Sedimentary Research, A64, 500 507.

Taboada, T.; A. M. Cortizas ; C. Garcia, and E.G. Rodeja 2006. Particle-size fractionation of titanium and zirconium during weathering and pedogenesis of granitic rocks in NW Spain. Geoderma, 131 (2006), pp. 218-236.

Yossif, T.M. 2017. Soil resources potentialities of some areas adjacent to BaniMazar-El-Boiety road, West of El-Minia, Egypt. J. Adv. Agric. Res. Fac. Agric. Saba Basha. Vol. 22 (3), 2017.

Al-Eryan, M.A.S. and S. Sh. El-Tabbakh. 2004. Forecasting yield of corn, zea may infested with corn leaf aphid, Rhopalo- siphum maidis. J. Appl. Ent. 128 (4) 312-315.

Anupam Sharma,V.K . Chandla and D. R.Thakur. 2012. Biodiversity and pathogenicity potential of mycoflora associated with Brahmina coriacea in potato fields of North-Western Indian hills. J.Entom.9(6):319-331.

Bhagat, R. M., N. P. Kashyap and C. P.Viji. 2001. Management of white grubs through insecticides. Pesticide Rese. J.13(2):247-249.

Bhagat, R. M., R. B. L. Gupta and C. P. S. Yadava. 2003. Field efficacy of two entomopathogenic fungal formulations against white grubs in Himachal Pradesh. Indian J. Entom. 65(1):76-81.

Chandel, R.S. 1992. Bioecology and control of Brahmina coriacea (Hope) Ph. D. Thesis, Department of Entomology and Apiculture, Dr. YSP, University of Horticulture and Forestry, Nauni, Solan, Himachal Pradesh, India p 170.

Chandla, V. K. and R. S. Chandel. 2007. Integrated management of soil pests of potato in higher hills of Himachal Pradesh. National Academy Sci. Letters 30(7/8):221-222.

Chandel, R. S, V. K. Chandla and K. R. Dhiman.2005. Vulnerability of potato white grub to entomogenous fungi and nematodes. Potato J.32(3/4):193-194.
Chiarappa.I, E. J. Moor, and A. H Strickland. 1970.Introduction in crop loss assessment methods. FAO manual on the evaluation and prevention of losses by pests. diseases and weeds. Rome FAO.

Gage, S.H. and M. K. Mukerji. 1978. Crop losses associated with grasshoppers in relation to economics of crop production.J.Econ. Entomol. 71, 487-498.

Gblebiowska A.Z. and W. Romankov. 1968. Trials to assess losses caused by cecidomyid larvae to foxtail - grass (Alopecurus pratensis L.). (In Pollish with English and Russian summaries ) Roczn,Nauk rolin (A),93:685-699.

Judenko, E. 1973.Analytical method for assessing yield losses caused by pests on cereal crops with and without pesticides. Tropical pest bulletin (2): 5-31.

Kokate, K. D., V. K. Chandla., H. Nand and K. S. Negi. 1991. Management of white grub (Lachnosterna coriacea) in potato (Solanum tuberosum) fields of Shimla hills. Indian J.Agri. Sci.61(10):787-788.

Khosla, R. K. 1976.Techniques for assessment of lossess due to pest and diseases of rice .Indian Jour . Agri. Sci 47(4),171-174.

Mehta, P.K, R.S. Chandel and Y.S. Mathur. 2010. Status of white grubs in North Western Himalaya. Jour. of Insect Sci. 23(1): 1-14.

Misra, S. S. 1995. White grub, Holotrichia (Lachnosterna) coracea (Hope) - a key pest of potatoes in Himachal Pradesh, India. J.Entomol. Rese.19(2):181-182.

Misra, S. S., and H. C. Sharma 1987. Assessment of crop losses due to major insect pests (white grubs and cutworms) of potato crop. Annual Sci. Rep. Central Potato Research Institute, India.; 1988. :142-149.

Mohammad, M., A. R. Wani, S. H. Kha and A. Abass. 2016. Pest complex of potato (Solanum tuberosum L.) with special reference to management of white grub in northern districts of Kashmir Valley. J. Agric. Sci., Toronto., 8(3):151-161. 29.

Pradhan, S. 1964.Assessment of losses cased by insect pests of crops and estimation of insect population. InEntomo.in india. N.C.plant(Ed),Entmo. Soci. Of india, New Delhi,p.17-58.

Puja, R., Y. Thakur, A. Sharma, A. Sharma and V. K.Chandla. 2009. Biointensive management of white grubs with botanical extracts in indigenous cow (Hariana) urine. Potato J.36(1/2):61-64. 7.

Rolston, L. H and T.Barlow. 1980. Insecticide control of a white grub, Phyllophaga ephilida Say (Coleoptera: Scarabaeidae) on sweet potato. J.Georgia Entomological Soci.15(4):445-449.

Sanaa, A. M. I. 2002. Azadirachtin affects growth and survival of the mole-cricket Gryllotalpa gryllotalpa (Orthoptera: Gryllotalpidae). Egyptian J. of Agric. Rese. 80(2):665673.13 ref.

Singh, S.P. 1987. Occurrence of Metarrhizium anisoplae (Metch.) Sorkin on white grubs in potato fields. Current Rese.7(10):173. 
Steel, R.G.D. and J.H.Torrie. 1981.Principles and procedures of statistics .Abiometric approach.2nd Ed.Mc Grow.Hill Kogahusha Ltd.pp.633.

Stern, V. N., R. F. Smith, R. V. Bosch and K. S.Hagen. 1959.The integrated control concept, Hilgarda 29(2): 81101.

Stone, J. D and L.P. Pedigo. 1972 Development and economic injury level of the green clover worm on soybean in lowa. J .economic entomo.65.192-201.

Veenakumari, K. and G. K. Veeresh. 1982. Evaluation of different methods of inoculation for the production of the milky white disease caused by the bacterium, Bacillus popilliae Dutky on the white grub, Holotrichia serrata Fabricius. J. Biol.Ecol.ogy; 1982. 2(1):1-7.
Weiss, H.B., and E.L.Dickerson. 1918. The European mole cricket Gryllotalpa gryllotalpa, an introduced insect pest. Journal of NewYork Entomological Society 26: 18-23.

Zaghloul,A,O. 1982.Bioecollogy of Earias vittella (fab) and assessment of losses in cotton due to bollworms . College of Agri. UAS,Bangalase, India.

Zahid, M. A., M. M. Islam, M. H. Reza, M. H. Z. Prodhan and M. R. Begum. 2008. Determination of economic injury level of Helicoverpa armigera (Hubner) in chickpea. Bangladesh J. Agril. Res. 33(3): 555 - 563.

Zaki, F. A., Z. H. Bhat and A. R.Wani. 2007. Field evaluation of some insecticides against cutworm and white grub in potato. Indian J. Prote.35(1):121-122. 


\section{الملخص العربي}

\section{خسائر محصول البطاطس الناجمة عن الإصابة وبالحفار والجعل ذو الظهر الجامد بناء علي المعاملة}

\section{بالمبيدات في منطقة -النوبارية مصر}

عماد مصطفى العدوى، عثمان أحمد زغلول، أحمد محمد كردى، محمد محروس الثاذلى، ماجدة محمد خطاب

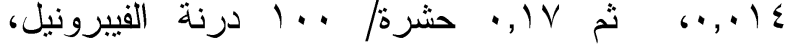
الكلوروبيروفوس ميثيل، فينتروثيون، ديمثويت،

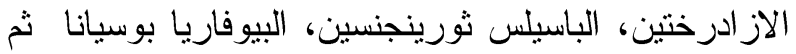

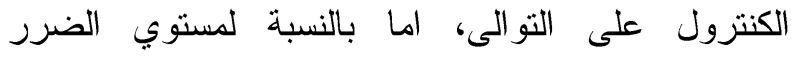
الاقتصادي لحشرة Brahmins coriacea.(Hope) كانت

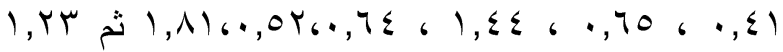
حشرة / . . . لكل من مبيد الفيبرونيل، الكلوروبيروفوس

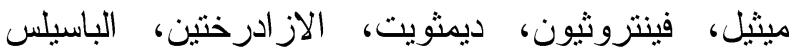
ثورينجنسين، البيوفاريا بوسيانا ثم الكنترول على التوالى في حين اظهرت النتائج خلال موسم 0 ـ ب ب لحشرة الحفار Gryllotalpa: gryllotalpa (L)

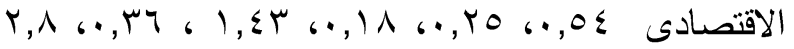
ثم هب, • حشرة / . .1 درنة لكل من مبيد الفيبرونيل،

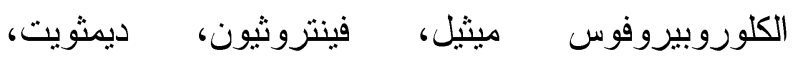
الاز ادرختين، الباسيلس ثورينجنسين، البيوفاريا بوسيانا ثمئي الكنترول على التوالى .في حين كان مستوى الضرر Brahmins coriacea.(Hope) الاقتصادى لحشرة الجعال

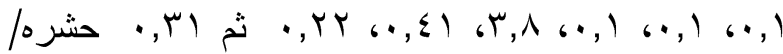
•. (ادرنة لكل من مبيد الفيبرونيل، الكلوروبيروفوس ميثيل، فينتروثيون، ديمثويت، الازادرختين، الباسيلس ثورينجنسين، البيوفاريا بوسيانا ثم الكنترول على التو الى.

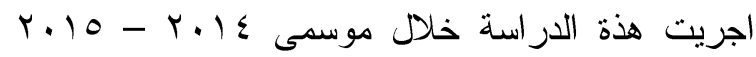
على درنات البطاطس من اجل تقييم الخسائر الناتجة عن هن كل من حشرة الحفار Gryllotalpa gryllotalpa (L) وحشرة الجعال Brahmins coriacea.(Hope) حيث تم معاملة الدرنات بسبعة طعوم من المبيدات الحشرية وفقا للجرعات الموصي بها وذللك في عمر • V وم1 يوم من الزر اعة

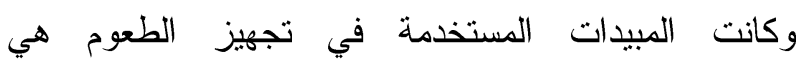
الفيبرونيل ، الكلوروبيروفوس ميثيل، فينتروثيون، ديمثويت، الاز ادرختين، الباسيلس ثورينجنسين ثم البيوفاريا بوسيان. حيث اظهرت النتائج المتحصل عليها خلال موسم الصيف ـ ا.ب ان نسبة الخسائر في درنات البطاطس كانت

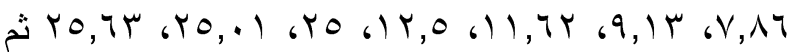
•\% لكل من الفيبرونيل، الكلوروبيروفوس ميثيل، فينتروثيون، ديمثويت، الاز ادرختين، الباسيلس ثورينجنسين، البيوفاريا بوسيانا ثم الكنترول على التوالى. اما خلال

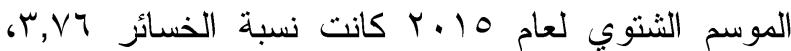
צ צ, Y, الفيبرونيل، الكلوروبيروفوس ميثيل، فينتروثيون، ديمثويت، الاز ادرختين، الباسيلس ثورينجنسين، البيوفاريا بوسيانا ثم

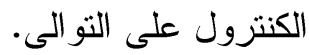

ومن الجدير بالذكر أن نسب الخسارة تعتبر خطوة أساسية لتحديد سبعة مستويات إصابة اقتصادية لكل آفة بـان حشرية. حيث كانت قيمة مستوى الضرر الاقتصادي Gryllotalpa خلال موسم ع ا.ب لحشرة الحفار (EILS)

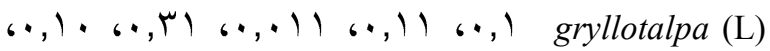

